\title{
Antioxidative Properties of Blighia sapida K.D. Koenig Stem Bark Extract and Inhibitory Effects on Carbohydrate Hydrolyzing Enzymes Associated with Non-Insulin Dependent Diabetes Mellitus
}

\author{
Oluwafemi Adeleke Ojo*, Basiru Olaitan Ajiboye, Oluwatosin Debbie Imiere, Oluwatosin Adeyonu, \\ Israel Olayide, Adewale Fadaka
}

\section{Oluwafemi Adeleke Ojo*, Basiru Olaitan Ajiboye, Oluwatosin Debbie Imiere, Oluwatosin Adeyonu, Israel Olayide, Adewale Fadaka}

Phytomedicine, Biochemical Toxicology and Diabetes Research Laboratories, Department of Biochemistry, Afe Babalola University, Ado-Ekiti, Ekiti State, NIGERIA.

\section{Correspondence}

Oluwafemi Adeleke Ojo

Department of Biochemistry, Afe Babalola University, Ado-Ekiti, NIGERIA.

Phone no: 234-703-782-4647

E-mail: oluwafemiadeleke08@gmail.com

History

- Submission Date: 05-10-2017;

- Review completed: 22-12-2017;

- Accepted Date: 08-01-2018

DOI : 10.5530/pj.2018.2.63

Article Available online

http://www.phcogj.com/v10/i2

Copyright

(C) 2018 Phcog.Net. This is an openaccess article distributed under the terms of the Creative Commons Attribution 4.0 International license.

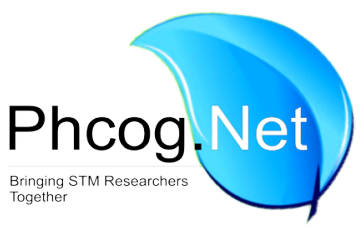

\begin{abstract}
Background and aim: In Africa, the fruit, seed, leaf, and stem of Blighia sapida K.D. Koenig are used as remedy for a range of diseases. This study characterized the phytochemicals, assessed the antioxidant and inhibitory properties of the stem bark of Blighia sapida. Materials and methods: Samples were consecutively extracted using ethanol solvent and investigated for phenol content, DPPH radical scavenging abilities, iron chelation, reducing power, $\alpha$-amylase and $\alpha$-glucosidase activities as markers of in vitro anti-diabetic activities. Phytochemicals were analyzed using gas chromatography-mass spectrometry (GC-MS) analysis. Results: The extract had radical scavenging capabilities, iron chelation and reducing power. Furthermore, the results reveal the extract had considerably high $\alpha$-glucosidase and $\alpha$ - amylase inhibitory activities as the concentration increases with $I_{50}$ values of $4.17 \pm 0.24 \mathrm{mg} / \mathrm{mL}$ and $5.30 \pm$ $1.25 \mathrm{mg} / \mathrm{mL}$, respectively. Enzyme kinetic studies indicated that the extract displayed uncompetitive inhibitor for $\alpha$-glucosidase and was a competitive inhibitor of $\alpha$-amylase. The ethanolic extract is rich in several aromatic phenolic compounds and long chain aliphatic acids. Conclusion: These results reveal the bark possessed antioxidant as well as $\alpha$-glucosidase and $\alpha$-amylase inhibitory activities.
\end{abstract}

Key words: Blighia sapida K D Koenig, $\alpha$-amylase, $\alpha$-glucosidase, Antidiabetic, Antioxidant activity.

\section{INTRODUCTION}

Diabetes mellitus is a metabolic disorder that causes disturbances of carbohydrate, fat and protein metabolism, leading to several complications such as nephropathy, neuropathy, and retinopathy. Current statistics suggest that about 382 million people are living with diabetes worldwide and this number is projected to increase to 552 million by 2035. In Africa, 19.8 million people are diagnosed with the disease while another 12.4 million are undiagnosed. ${ }^{1}$ (IDF 2014). The search for the discovery of anti-diabetic drugs from medicinal plants is an important strategy required to combat the widespread nature of diabetes mellitus in the world. This is because present synthetic drugs have many disadvantages ranging from limited efficacy and several side effects such as weight gain and chronic tissue damage. ${ }^{2}$ (Kane et al. 2005). However, current therapeutic strategy for the control of postprandial hyperglycemia is the inhibition of two key members of exo-acting glycoside hydrolases ( $\alpha$-glucosidase and $\alpha$-amylase), resulting in a protracted delay of carbohydrate digestion to absorbable monosaccharides (Kawamura-Konishi et al.
2012). Therefore, $\alpha$-glucosidase and $\alpha$-amylase inhibitors will ultimately reduce the flow of glucose from complex dietary carbohydrates into the bloodstream, diminishing the postprandial hyperglycemia. Therefore, the search for alternative agents with potent antioxidative properties that could also decrease postprandial hyperglycemia, thereby providing a holistic avenue to control hyperglycemia and other diabetic complications resulting from oxidative stress is of utmost importance. One of such plants used in the management of this disease in Africa is Blighia sapida K.D. Koenig.

Blighia sapida K.D. Koenig, also known as 'Akee apple', belongs to the plant family called Sapindaceae. There are different species of this plant, which include B. sapida, B. welwitschii and B. unijugata (Keay 1999). B. sapida is a familiar tree often planted to provide shade from hot sun. It is known locally as 'Isin' in Yoruba, 'Gwanja kusa' in Hausa and 'Okpu' in Igbo (Keay 1999). B. sapida is about $25 \mathrm{~m}$ high and $2.5 \mathrm{~m}$ in girth, with a heavy evergreen crown. $B$.

Cite this article: Ojo OA, Ajiboye BO, Imiere OD, Adeyonu O, Olayide I, Fadaka A. Antioxidative Properties of Blighia sapida K.D. Koenig Stem Bark Extract and Inhibitory Effects on Carbohydrate Hydrolyzing Enzymes Associated with Non-Insulin Dependent Diabetes Mellitus. Pharmacog J. 2018;10(2):376-83. 
sapida is a native of West Africa. It extends from Senegal to Gabon. It is also cultivated in India and tropical America. B. sapida is well distributed throughout Nigeria and found in the drier forest of the savannah region (Esuoso and Odetokun 2005). B. sapida is a medicinal plant commonly used by traditional healers in Nigeria, and highly valued in Africa for the treatment of various ailments (Owonubi 1996). The fruit has an inhibitory effect against $\alpha$-glucosidase and $\alpha$-amylase as reported by (Kazeem et al. 2014). B. sapida root extract has been shown to have hypoglycemic effect in normoglycemic rats (Saidu et al. 2012). B. sapida bark extract have been shown to ameliorate pancreatic $\beta$-cell dysfunction (Ojo et al., 2017). However, an attempt at understanding the pharmacological features of these plants with their different chemical compound that may hitherto poses hypoglycemic potentials necessitated this study. Thus, we conducted a comprehensive and systematic investigation of the in-vitro antioxidant as well as $\alpha$-glucosidase and $\alpha$-amylase inhibitory activities of extracts of B. sapida K.D. Koenig using complementary in vitro models, along with identification of bioactive compounds as well as establishing the mechanisms of $\alpha$-glucosidase and $\alpha$-amylase inhibitions via the enzyme kinetics approach.

\section{MATERIALS AND METHODS}

\section{Chemicals and reagents}

$\alpha$-Glucosidase from Saccharomyces cerevisiae, porcine pancreatic amylase, p-nitrophenyl-a-D-glucopyranoside (pNPG), $p$-nitrophenol, gallic acid, and potassium ferricyanide were obtained from Sigma-Aldrich, Germany. Starch, dinitrosalicylic acid (DNS), maltose, ethanol, trichloroacetic acid, 1,10-phenanthroline, gallic acid, FeSO4, potassium ferricyanide, ferric chloride, dimethylsulfoxide (DMSO), 1,1-diphenyl-2-picrylhydrazil (DPPH), thiobarbituric acid and Folin Ciocalteau reagents were obtained from Merck Chemical Company, Germany.

\section{Plant material}

Fresh stem bark peelings of Blighia sapida K.D. Koenig were collected at a local farm Abeokuta, Ogun State. Identification and authentication was previously done by (Ojo et al., 2017).

\section{Preparation of Extract}

Fresh stem bark was air-dried in the laboratory at ambient temperature $\left(30 \pm 2^{\circ} \mathrm{C}\right)$, pulverized using a laboratory mechanical grinder and the ground powders obtained stored until further use. The powdered sample $(100 \mathrm{~g})$ was extracted with a solvent of $70 \%$ ethanol in water for $48 \mathrm{~h}$. The filtrate was concentrated and evaporated to dryness at $60^{\circ} \mathrm{C}$, using rotary evaporator. The yield was as shown below and the dry extract was stored at $4^{\circ} \mathrm{C}$ until further analysis.

$$
\text { Percentage yield }=\frac{\text { Weight of the dry extract }}{\text { Weight of powdered leaves }} \times 100
$$

\section{Determination of total phenol content}

The total phenol content of the bark extract was determined (as gallic acid equivalent) as described by McDonald et al. (2001) with slight modifications. Briefly, $200 \mu \mathrm{L}$ of the extract dissolved in $10 \%$ DMSO $\left(240 \mu \mathrm{g} \mathrm{mL}^{-1}\right)$ was incubated with $1.0 \mathrm{~mL}$ of Folin Ciocalteau reagent (diluted 10 times) and $800 \mu \mathrm{L}$ of $0.7 \mathrm{~mol} \mathrm{~L}^{-1} \mathrm{Na}_{2} \mathrm{CO}_{3}$ for $30 \mathrm{~min}$ at room temperature. Then, the absorbance was measured at $765 \mathrm{~nm}$ on a Shimadzu UV mini 1240 spectrophotometer (Shimadzu, Japan). All measurements were done in triplicates. Results were expressed as mg GAE/ 100 g dry ethanol extracts.

\section{Determination of Reducing Power}

The reducing power of the bark extract was determined by reduction a $\mathrm{FeCl}_{3}$ solution as described by Pulido et al. (2000). A $2.5 \mathrm{~mL}$ aliquot of the extract was mixed with $2.5 \mathrm{~mL}, 200 \mathrm{mM}$ sodium phosphate buffer ( $\mathrm{pH}$ 6.6) and $2.5 \mathrm{~mL}, 1 \%$ potassium ferricyanide. The solution was incubated at $50{ }^{\circ} \mathrm{C}$ for $20 \mathrm{~min}$ and then $2.5 \mathrm{~mL}, 10 \%$ TCA was added. The sample was then centrifuged at $650 \mathrm{~g}$ for $10 \mathrm{~min}$ and $5 \mathrm{~mL}$ of the supernatant was mixed with an equal volume of water and $1.0 \mathrm{~mL}, 0.1 \%$ ferric chloride. The same treatments were performed to a standard ascorbic acid solution and the absorbance read at $700 \mathrm{~nm}$. The reducing power was then calculated and expressed as percentage inhibition.

\section{Determination of Iron Chelation Ability}

The $\mathrm{Fe}^{2+}$ chelating ability of bark extract was determined by employing a modified method of (Minotti and Aust 1987) with a slight modification by Puntel et al. (2005). Freshly prepared $500 \mu \mathrm{mol} \mathrm{L}^{-1} \mathrm{FeSO}_{4}(150 \mu \mathrm{L})$ was added to a solution containing $168 \mu \mathrm{L}$ of $0.1 \mathrm{~mol} \mathrm{~L}^{-1}$ Tris- $\mathrm{HCl}(\mathrm{pH}$ 7.4), together with $218 \mu \mathrm{L}$ saline and an ethanol extract (1-5 mg/mL). The solution was incubated for $5 \mathrm{~min}$, followed by addition of $13 \mu \mathrm{L}$ of $0.25 \% 1,10$-phenanthroline (w/v). Absorbance was read at $510 \mathrm{~nm}$. Fe chelating ability was expressed as percentage inhibition.

\section{DPPH radical scavenging activity}

The free radical scavenging activity of the extract was determined using a slightly modified method described by Tuba and Gulcin (2008). A $0.3 \mathrm{mmol} \mathrm{L} \mathrm{L}^{-1}$ solution of DPPH was prepared in methanol and $500 \mu$ $\mathrm{L}$ of this solution was added to $1 \mathrm{~mL}$ of the extract (dissolved in $10 \%$ DMSO) at different concentrations $(1-5 \mathrm{mg} / \mathrm{mL})$. These solutions were mixed and incubated in the dark for $30 \mathrm{~min}$ at room temperature. Absorbance was read at $517 \mathrm{~nm}$ against blank lacking scavenger.

\section{Determination of a-amylase inhibitory activity}

The $\alpha$-amylase inhibitory activity was determined as described by Shai et al. (2010). A volume of $250 \mu \mathrm{L}$ of ethanol extract at different concentrations $\left(1-5 \mathrm{mg} \mathrm{mL}^{-1}\right)$ was incubated with $500 \mu \mathrm{L}$ of porcine pancreatic amylase $\left(2 \mathrm{U} \mathrm{mL}^{-1}\right)$ in $100 \mathrm{mmol} \mathrm{L}^{-1}$ phosphate buffer $\left(\mathrm{pH} \mathrm{6.8)}\right.$ ) at $37^{\circ} \mathrm{C}$ for $20 \mathrm{~min} .250 \mu \mathrm{L}$ of $1 \%$ starch dissolved in $100 \mathrm{mmol} \mathrm{L}^{-1}$ phosphate buffer ( $\mathrm{pH}$ 6.8) was added to the solution and incubated at $37^{\circ} \mathrm{C}$ for 1 h. $1.0 \mathrm{~mL}$ of DNS color reagent was then added and boiled for $10 \mathrm{~min}$. Absorbance was read at $540 \mathrm{~nm}$ and the inhibitory activity was expressed as a percentage of a control sample without inhibitors. All assays were carried out in triplicate.

$$
\alpha-\operatorname{amylase} \text { inhibition }(\%)=\frac{\mathrm{A}_{540 \text { control }}-\mathrm{A}_{540 \text { sample }}}{\mathrm{A}_{540 \text { control }}} \times 100
$$

\section{Mode of a-amylase inhibition}

The mode of inhibition of $\boldsymbol{\alpha}$-amylase by the bark extract was determined by employing a modified method described by Ali et al. (2006). Briefly, $250 \mu \mathrm{L}$ of the $\left(2.5 \mathrm{mg} \mathrm{mL}^{-1}\right)$ extract was pre-incubated with $250 \mu \mathrm{L}$ of $\alpha$-amylase solution for $10 \mathrm{~min}$ at $37^{\circ} \mathrm{C}$ in one set of tubes. In another set of tubes, $\boldsymbol{\alpha}$-amylase was pre-incubated with $250 \mu \mathrm{L}$ of phosphate buffer ( $\mathrm{pH}$ 6.9). Two hundred and fifty $\mu \mathrm{L}$ of the starch solution at increasing concentrations $\left(0.3-5.0 \mathrm{mg} \mathrm{mL}^{-1}\right)$ was added to both sets of reaction mixtures to start the reaction. The solution was then incubated for $10 \mathrm{~min}$ at $37^{\circ} \mathrm{C}$ and boiled for $5 \mathrm{~min}$ after addition of $500 \mu \mathrm{L}$ of DNS to stop the reaction. The amount of reducing sugars released was determined using a maltose standard curve and converted to reaction velocities. A double reciprocal (Lineweaver-Burk) plot $(1 / \mathrm{v}$ versus $1 /[\mathrm{S}])$ where $\mathrm{v}$ is reaction velocity and $[S]$ is substrate concentration, was plotted to determine the mode of inhibition.

\section{Determination of a-glucosidase inhibitory activity}

The $\alpha$-glucosidase inhibitory activity was determined as described by Ademiluyi and Oboh (2013). Briefly, $250 \mu \mathrm{L}$ of the extract, at different concentrations $\left(1-5 \mathrm{mg} \mathrm{mL}^{-1}\right)$, was incubated with $500 \mu \mathrm{L}$ of $1.0 \mathrm{U} \mathrm{mL}^{-1}$ 
$\alpha$-glucosidase solution in $100 \mathrm{mmol} \mathrm{L}^{-1}$ phosphate buffer ( $\mathrm{pH} 6.8$ ) at $37^{\circ} \mathrm{C}$ for $15 \mathrm{~min}$. Thereafter, $250 \mu \mathrm{L}$ of a pNPG solution $\left(5 \mathrm{mmolL}^{-1}\right)$ in $100 \mathrm{mmol} \mathrm{L}^{-1}$ phosphate buffer ( $\mathrm{pH}$ 6.8) was added and the solution was further incubated at $37^{\circ} \mathrm{C}$ for 20 min more. Absorbance was read at $405 \mathrm{~nm}$ and the inhibitory activity was expressed as the percentage of a control sample without inhibitors.

$$
\alpha-\text { glucosidase inhibition }(\%)=\frac{\mathrm{A}_{405 \text { control }}-\mathrm{A}_{405 \text { sample }}}{\mathrm{A}_{405 \text { control }}} \times 100
$$

\section{Mode of a-glucosidase inhibition}

The mode of inhibition of a-glucosidase by the stem bark extract was determined as described by Ali et al. (2006). Briefly, $50 \mu \mathrm{L}$ of the $\left(2.5 \mathrm{mg} \mathrm{mL}^{-1}\right)$ extract was pre-incubated with $100 \mu \mathrm{L}$ of $\alpha$-glucosidase solution for $10 \mathrm{~min}$ at $37^{\circ} \mathrm{C}$ in one set of tubes. In another set of tubes, $100 \mu \mathrm{L}$ a-glucosidase was pre-incubated with $50 \mu \mathrm{L}$ of phosphate buffer (pH 6.9). $50 \mu \mathrm{L}$ of pNPG at increasing concentrations $\left(0.63-2.0 \mathrm{mg} \mathrm{mL}^{-1}\right)$ was added to both sets of reaction mixtures to start the reaction. The solution was incubated for $10 \mathrm{~min}$ at $37^{\circ} \mathrm{C}$ and $500 \mu \mathrm{L}$ of $\mathrm{Na}_{2} \mathrm{CO}_{3}$ was added to stop the reaction. The amount of reducing sugars released was determined using a para-nitrophenol standard curve and converted to reaction velocities. A double reciprocal (Lineweaver-Burk) plot (1/v versus $1 /[S]$ ) where $\mathrm{v}$ is reaction velocity and $[\mathrm{S}]$ is substrate concentration was plotted to determine the mode of inhibition.

\section{Gas chromatography-mass spectrometric (GC-MS) analysis}

The ethanol extract was subjected to GC-MS analysis. The analysis was carried out as described by Ibrahim et al. (2014). The carrier gas was ultra-pure helium at a flow rate of $0.7 \mathrm{~mL} \mathrm{~min}^{-1}$ and a linear velocity of $37 \mathrm{~cm} \mathrm{~s}^{-1}$. The injector temperature was set at $250^{\circ} \mathrm{C}$. The initial oven temperature was $60^{\circ} \mathrm{C}$, which was programmed to $280^{\circ} \mathrm{C}$ at the rate of $10^{\circ} \mathrm{C} \mathrm{m^{-1 }}$ with a hold time of $3 \mathrm{~min}$. Injections of $2 \mu \mathrm{L}$ were made in the split less mode with a manual split ratio of 20:1. The mass spectrometer was operated in the electron ionization mode at $70 \mathrm{eV}$ and electron multiplier voltage at $1859 \mathrm{~V}$. Other MS operating parameters were as follows: ion source temperature $230{ }^{\circ} \mathrm{C}$, quadrupole temperature $150^{\circ} \mathrm{C}$, solvent delay $4 \mathrm{~min}$ and scan range 50-700 amu. Compounds were identified by direct comparison of the retention times and mass fragmentation pattern with those from the National Institute of Standards and Technology (NIST) library.

\section{Data analysis}

Results of the three replicates were pooled and expressed as the mean \pm $\mathrm{SD}$. Differences between groups were assessed by an analysis of variance model and Tukey's test. The level of significance for the analyses was set at $p<0.05$. These analyses were performed by using the free software $\mathrm{R}$ version 3.1.1. (R Core Team, 2014).

\section{RESULTS AND DISCUSSION}

\section{Total Phenol Content}

The ethanol extract of Blighia sapida bark had $19.1 \%$ as its yield (Table 1). The total phenolic content of ethanol extract of Blighia sapida bark increases as the concentration ( $1-5 \mathrm{mg} / \mathrm{ml})$ of extract increases. At $5 \mathrm{mg} / \mathrm{ml}$, the extract of Blighia sapida had high phenol content of $19.92 \pm 0.12 \mathrm{mg}$ GAE/100g Table 2. However, ethanolic extract have high yields and contain a high total phenol content as the concentration increases. This is consistent with previous findings that ethanol is the best solvent for the extraction of a maximum yield of polyphenols compared to other solvents (Mohd-Esa et al. 2010; Ojo et al. 2014). Although no correlation analysis was carried out in this study, previous studies strongly correlate antioxidative effect to total polyphenol contents (Hossain et al. 2009).
Table 1: Percentage yield of Ethanol extract of Blighia sapida bark.

\begin{tabular}{cccc}
\hline Extract & Initial weight (g) & Final weight $(g)$ & \% Yield \\
\hline Ethanol & 100 & 19.1 & 19.1 \\
\hline
\end{tabular}

Table 2: Total Phenol contents of the Ethanol Extract of Blighia sapida Stem bark.

\begin{tabular}{cc}
\hline Concentration $(\mathrm{mg} / \mathrm{ml})$ & $(\mathrm{mg} \mathrm{GAE} / 100 \mathrm{~g})$ \\
\hline 1 & $7.45 \pm 0.09$ \\
2 & $9.80 \pm 0.13$ \\
3 & $12.75 \pm 0.11$ \\
4 & $14.85 \pm 0.01$ \\
5 & $19.92 \pm 0.12$
\end{tabular}

* Results are expressed as mean of three determinations \pm standard deviation.

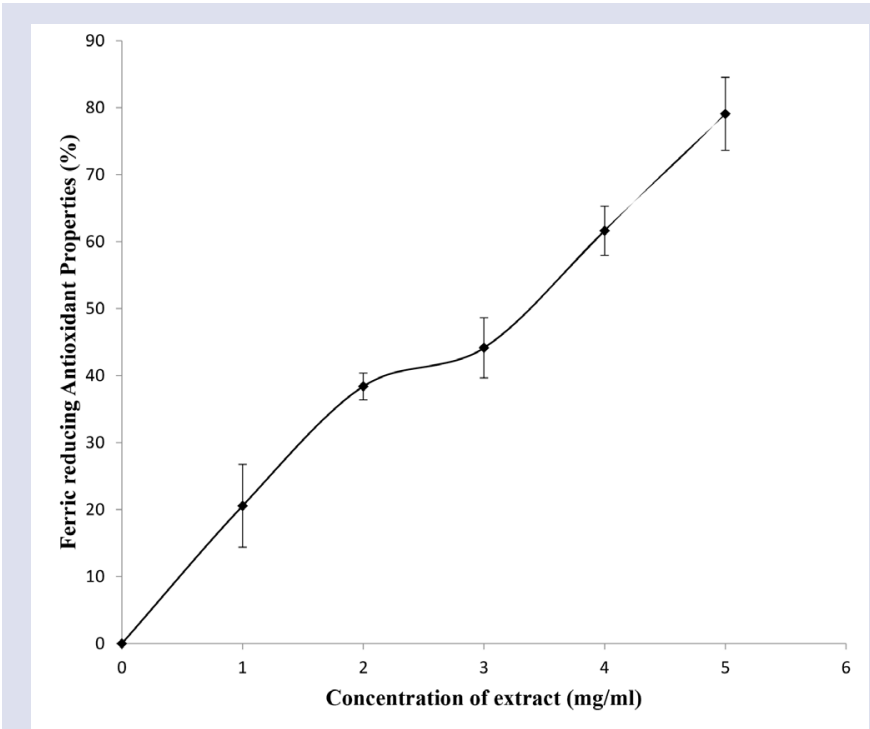

Figure 1: Ferric reducing antioxidant properties of ethanol extracts of Blighia sapida stem bark.

\section{Reducing Power}

Ethanol extracts of Blighia sapida bark showed significantly $(P<0.05)$ higher reducing power Figure 1 . The trend of the reducing capacity of the extracts was concentration dependent (1-5 mg/ml). Reducing power is an antioxidant defense system and the two mechanisms known to affect this property are electron transfer and hydrogen atom transfer (Dastmalchi et al. 2007; Ojo et al. 2014). The reducing capacity of the extracts could also indicate potential antioxidant activities (Oboh and Rocha 2007).

\section{DPPH radical scavenging ability}

The scavenging effect of extracts in the range $1-5 \mathrm{mg} \mathrm{mL}^{-1}$ on the DPPH radical increased with an increasing concentration of $B$. sapida extracts Figure 2. $\mathrm{IC}_{50}$ value for DPPH scavenging by the ethanol extracts of B. sapida was $2.53 \mathrm{mg} \mathrm{mL}^{-1}$. In the present investigation, B. sapida at different concentration demonstrated significant DPPH scavenging activity indicating its ability to act as radical scavengers. This study revealed that ethanol extracts of B. sapida stem bark scavenged DPPH free radicals. Thus, the observed DPPH radical scavenging ability might 


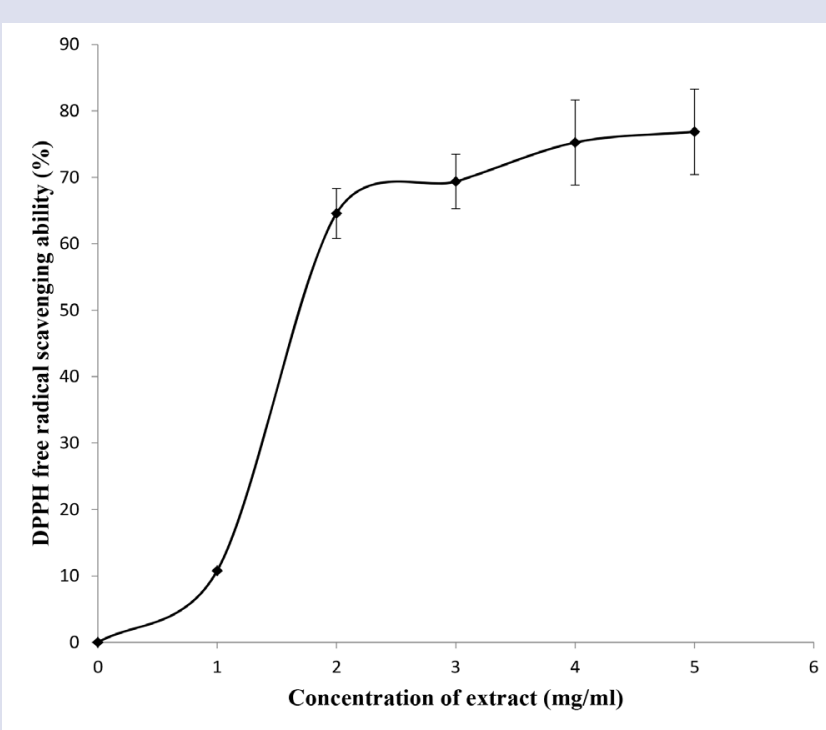

Figure 2: DPPH free radical scavenging ability of ethanol extracts of Blighia sapida stem bark.

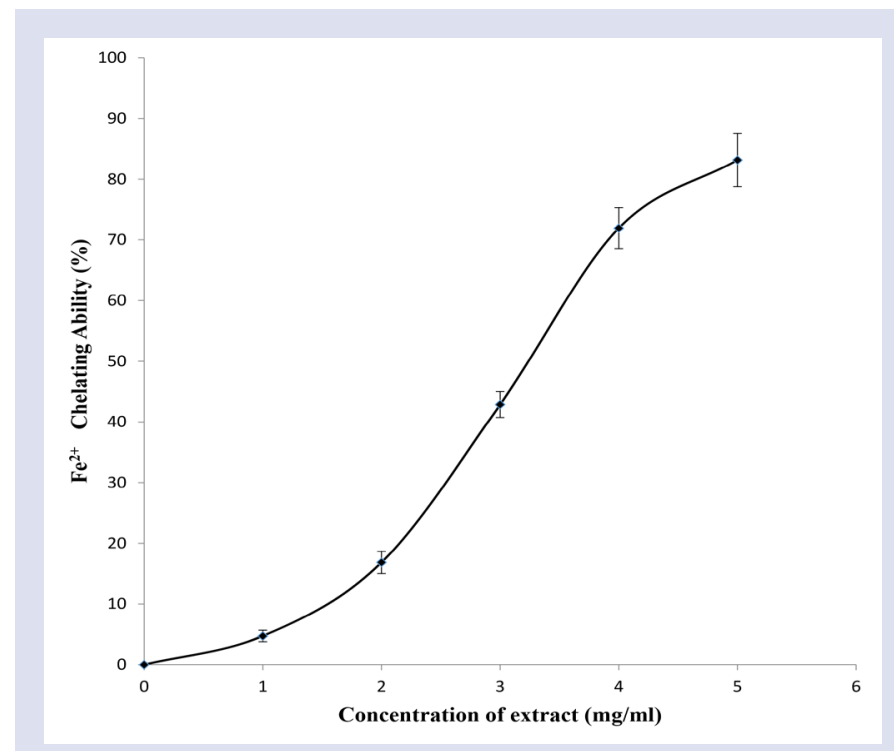

Figure 3: Iron chelating ability of ethanol extracts of Blighia sapida stem bark.

be attributed to the abundant phenols in the extracts. This is consistent with previous studies (Gyamfi and Yonamine 1999; Shim et al. 2003).

\section{Iron chelating ability}

Blighia sapida ethanol bark extract had a high chelating effect. $\mathrm{IC}_{50}$ values for the chelating effect of ethanol extracts of B. sapida bark was $3.29 \mathrm{mg} / \mathrm{mL}$. The trends of the chelating activity increased with increasing extract concentration of B. sapida bark (Figure 3). Furthermore, chelating iron could help prevent the generation of hydroxyl radicals. Iron serves as a metal catalyst in producing hydroxyl radicals from hydrogen peroxide (Oboh et al. 2008; Ojo et al. 2013a). The bark extract significantly chelates $\mathrm{Fe}^{2+}$ in a concentration dependent manner (1-5 mg/mL). By chelating
$\mathrm{Fe}^{2+}$, the generation of hydroxyl radicals in the Fenton reaction can be attenuated and thus prevent possible damage of hydroxyl radicals to biomolecules. Accumulation of iron has been reported to lead to an increase in free radicals and development of oxidative stress (Shim et al. 2003).

\section{a-amylase inhibitory activity}

Figure 4 shows the percentage inhibition of $a$-amylase ethanol extract of $B$. sapida bark. The fraction had appreciable in vitro inhibitory activity against $\alpha$-amylase. The $\mathrm{IC}_{50}$ value for the ethanol extract against a-amylase activity was determined from a dose-response curve to be $0.053 \pm 0.25 \mathrm{mg} / \mathrm{mL}$ (Table 3 ). The Lineweaver-Burke plot was generated to determine the mode of inhibition of the enzyme and the result showed that ethanol extract of B. sapida inhibited $\alpha$ - amylase in a competitive manner (Figure 6). It is an established fact that $\alpha$-amylase and a-glucosidase inhibitors from natural sources play a significant role in diabetic management. This is achieved via a decrease in postprandial hyperglycemia through inhibition of $\alpha$-amylase and $\alpha$-glucosidase actions (Adefegha and Oboh 2012). Furthermore, for effective control of postprandial hyperglycemia, moderate $\alpha$-amylase inhibition and potent $\alpha$-glucosidase inhibition provide better options for controlling the availability of dietary glucose for absorption in the intestinal tract (Kajaria et al. 2013). This is due to adverse effects associated with strong $\alpha$-amylase inhibition such as abdominal distension, flatulence, and diarrhea (Al-Zuhair et al. 2010). In this study, B. sapida ethanol extract demonstrated $\alpha$-amylase inhibition and $\alpha$-glucosidase inhibition, indicating a potential role as an anti-diabetic agent. The competitive inhibition of $\alpha$-amylase by the extract of $B$. Sapida bark suggests that the active inhibitory component(s) of the extract are structurally similar to the normal substrate of the enzyme. Therefore, it binds reversibly to the active site of the enzyme and occupies it in a mutually exclusive manner with the substrate (Shai et al. 2010). These high a-amylase inhibitory activity, might suggest the presence of more active compounds that could inhibit the breakdown of complex carbohydrates to oligosaccharides, thereby diminishing the effect of carbohydrate consumption on postprandial hyperglycemia. This is because some of the side effects associated with the currently available drugs for the management of T2D are linked with excessive inhibition of $\alpha$-amylase activity (Ademiluyi and Oboh 2013).

\section{a-glucosidase inhibitory activity}

Figure 5 shows the percentage inhibition of $\alpha$-glucosidase by ethanol extract of B. sapida bark. The fraction inhibited a-glucosidase activities in vitro in a dose dependent manner. The concentration of the extract required to cause $50 \%$ inhibition $\left(\mathrm{IC}_{50}\right.$ ) was $0.0417 \pm 0.24 \mathrm{mg} / \mathrm{ml}$ (Table 3 ). Figure 5 depicts that the mode of inhibition of $\alpha$-glucosidase by the ethanol extract of $B$. sapida is an un-competitive type of inhibition (Figure 7). For a-glucosidase inhibition, the strong inhibition of the enzyme displayed by the bark extract as shown by the $\mathrm{IC}_{50}$ values suggests that this extract is a potent $\alpha$-glucosidase inhibitor. Further study to ascertain the mode of inhibition $\alpha$-glucosidase by the extract of B. sapida bark showed the extracts inhibited the enzyme competitively. This suggests that the inhibitor binds exclusively to the enzyme substrate complex yielding an inactive enzyme-substrate-inhibitor complex (Bachhawat et al. 2011; Kazeem et al. 2013). Thus, the strong inhibition of $\alpha$-glucosidase by the extract would slow down the breakdown of disaccharides to liberate glucose, thereby reducing glucose absorption from the small intestine (Kwon et al. 2007). Furthermore, in spite of abundant reports on the $\alpha$-glucosidase inhibitory activities of extracts and pure compounds from plants from stem bark, only a few authors (Kang et al. 2012) to the best of our knowledge reported such a low $\mathrm{IC}_{50}$ value as found with the ethanol extract in our study. This observation might be connected to the phenol content in this extract, because polyphenolic fractions from plants have 


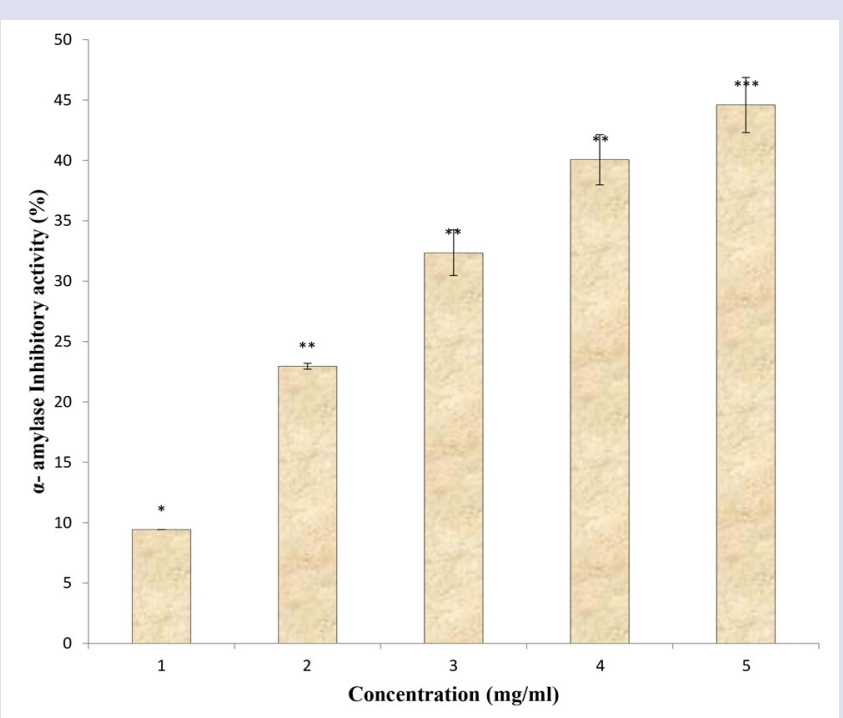

Figure 4: a-amylase inhibitory activities of ethanol extract of Blighia sapida bark.

Data are presented as mean \pm SD of triplicate determinations. $\left(^{* * * *}\right)$ Different symbol over the bars for a given concentration for each extract indicate a significant difference from each other (Duncan multiple range post hoc test, $p<0.05$ ).

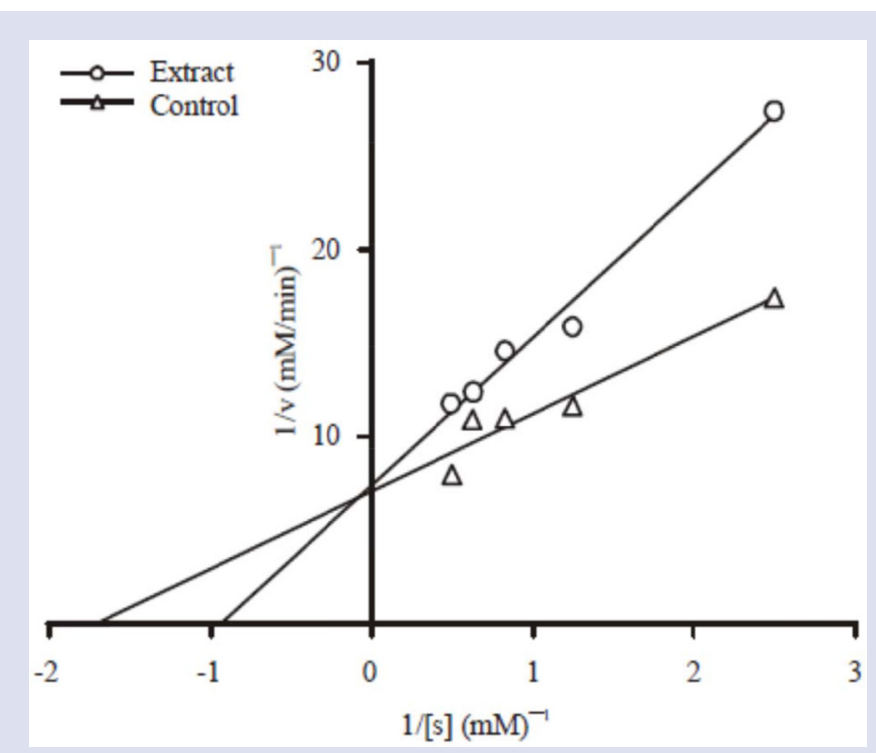

Figure 5: Mode of inhibition of a- amylase by ethanol extract of bark of Blighia sapida.

Table 3: IC50 values for the inhibition of a-glucosidase and a-amylase by ethanol extract of Blighia sapida bark.

\begin{tabular}{ccc}
\hline Fraction & \multicolumn{2}{c}{$\mathrm{IC}_{50}(\mathrm{mg} / \mathrm{ml})$} \\
\hline & a-glucosidase & a-amylase \\
Ethanol & $0.0417 \pm 0.24^{\mathrm{a}}$ & $0.0530 \pm 0.25^{\mathrm{b}}$ \\
\hline
\end{tabular}

Data are presented as mean \pm SD of triplicate determinations. a-b Different letters over the bars for a given concentration for each extract indicate a significant difference from each other (Duncan multiple range post hoc test, $\mathrm{p}<0.05$ ).

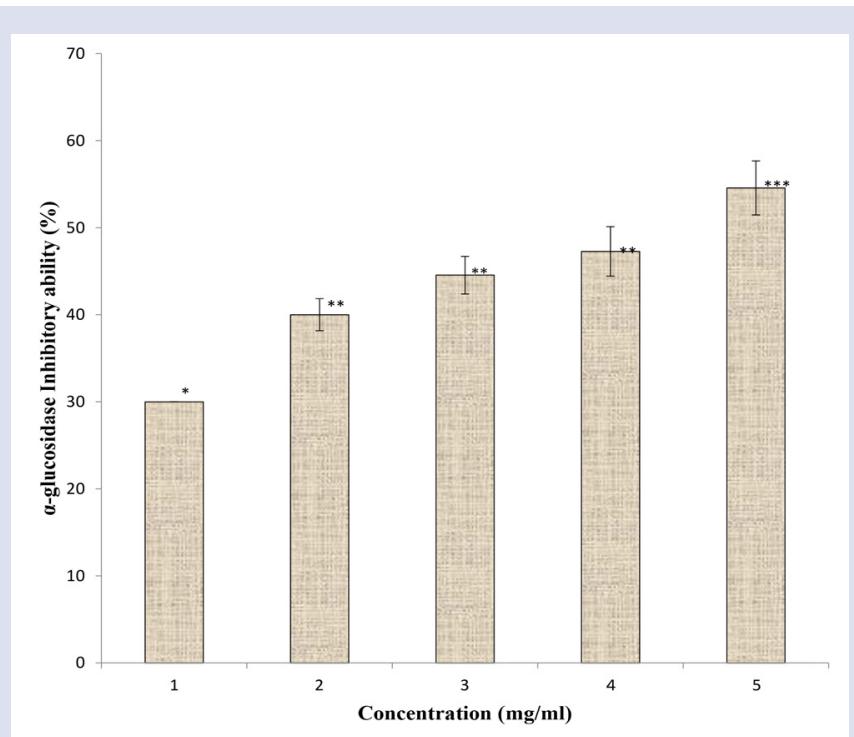

Figure 6: a-glucosidase inhibitory activities of ethanol extract of Blighia sapida bark.

Data are presented as mean \pm SD of triplicate determinations. $\left({ }^{*}{ }^{* * *}\right)$ Different symbol over the bars for a given concentration for each extract indicate a significant difference from each other (Duncan multiple range post hoc test, $p<0.05$ ).

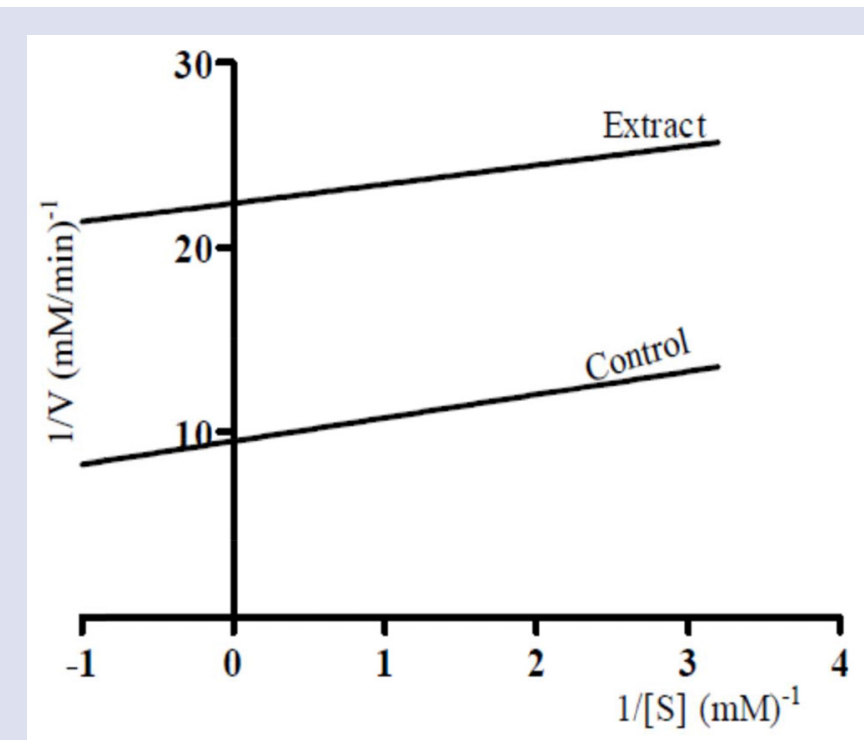

Figure 7: Mode of inhibition of a- glucosidase by ethanol extract of bark of Blighia sapida.

been shown to inhibit $\alpha$-glucosidase activity, allowing for tighter control of blood glucose (Kamiyama et al. 2010). The inhibitory effects of the extract of the B. sapida stem bark on the $\alpha$-amylase and $\alpha$-glucosidase activities may be attributed to the presence of phytochemicals such as polyphenols, tannins and saponins. However, previous studies attributed the medicinal property of the aqueous extract of this plant to the presence of saponins (Abolaji et al. 2007; Aderinola et al. 2007). Moreover, a water soluble pure compound named hypoglycin was isolated from this plant which also contributes to the plant hypoglycemic properties (Hassall and 


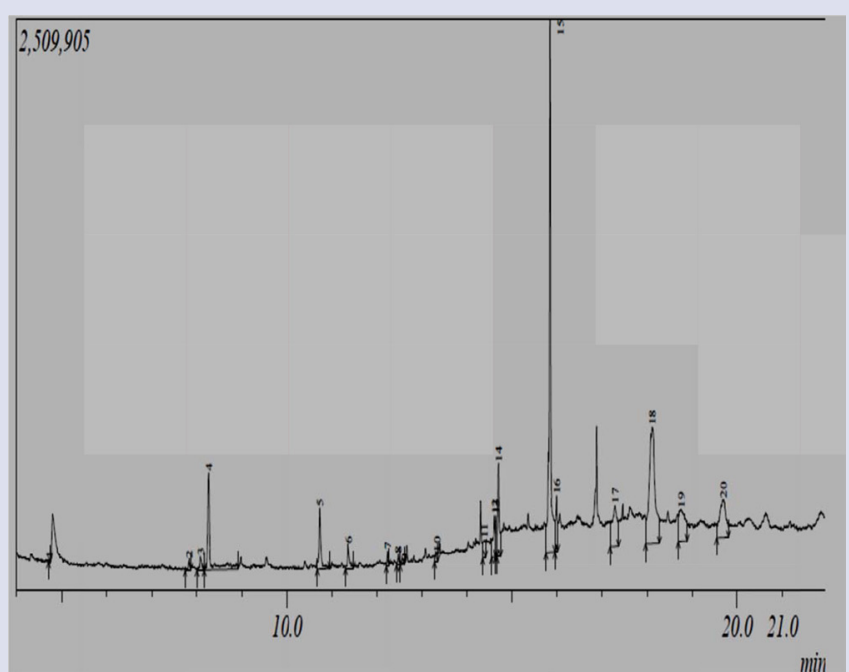

Figure 8: GC-MS Chromatogram of the ethanol extract of Blighia sapida bark.

Name: 2-Methoxy-4-vinylphenol

Name: 2,4,6-Trimethylanisole

Name: 4-hydroxy-3,5,6-trimethyl-4-(3-oxo-1-butenyl) Name: 4-hydroxy3,5,5-trimethyl-4-(3-oxo-1-butenyl)

Name: 1,2-Benzenedicarboxylic acid

Reyle 1955). This could also give the reason behind the inhibitory activity

shown by the ethanol extract of B. sapida bark towards these enzymes.

\section{GC-MS analysis}

The GC-MS chromatogram of the fraction is presented in Figure 8 . Twenty peaks were visible in the chromatogram and the various chemical constituents at those peaks were identified from the NIST library Table 4 and the compounds detected correspond to aromatic phenols, aromatics containing ether, ester and acid moieties and long chain aliphatic acids. The retention time and molecular mass of the detected compounds are provided in Table 4. 2-Methoxy-4-vinyl phenol, 1-eicosanol, (-)-mellein, diethyl phthalate, 4-((1E)-3-hydroxy-1-propenyl)-2-methoxy phenol, phenol, 3-isopropoxy-5-methyl-, phthalic acid, heptyl 4-nitrophenyl ester, 9,9-dimethoxy bicyclo [3.3.1] nona-2,4-dione, di-dodecyl phthalate, 9,9-di-methoxybicyclo [3.3.1]nona-2,4-dione, phytol, 9,12-cctadecadienoic acid (Z,Z)-, 1,2-9,9-dimethoxybicyclo[3.3.1]nona-2,4-dione, 9-octadecenamide, (Z)-, 9-octadecenamide (Z)-, citronellol epoxide (R or S), 9,19-cyclolanostan-3-ol, acetate, (3.beta.)-, cholest-4-en-3-one, 9,9-dimethoxybicyclo [3.3.1]nona-2,4-dione, cis-1,2-cyclododecanediol, were present in the ethanol extracts of $B$. sapida. The most abundant phytochemicals $(>50 \%)$ in the extract as identified by the library were phenolic (2-methoxy-4-vinyl phenol) and phthalic acid (1,2-benzenedicarboxylic acid) (Figure 9). The possible bioactive compounds in the ethanol extract of B. sapida bark were detected using GC-MS analysis. Although, identification of pure compounds has not been recorded. Hence, the antidiabetic action of the ethanol extract of B. Sapida bark in our study could possibly be attributed to the presence of these compounds as well, while not discounting the possible contributions of the other detected phytochemicals. Phytochemical analysis of the bark resulted in the identification of compounds with potential medicinal usage (Singh et al. 2012). For example, 2-Methoxy-4-vinylphenol, has already been implicated in a wide array of therapeutic applications such as antioxidant, anti-microbial and anti-inflammatory. Phytols are said to be cancer preventive. Other antioxidants present were phenol, 3-isopropoxy-5-methyl-, 4-((1E)3-hydroxy-1-propenyl)-2-methoxyphenol. Hypo-cholesterolemic com-

Table 4: Identified compounds of the ethanol extract of Blighia sapida bark by GC-MS.

\begin{tabular}{|c|c|c|c|}
\hline Peak No & Compound & Retention time & Molecular mass \\
\hline 1 & 2-Methoxy-4-vinylphenol & 4.73 & 150 \\
\hline 2 & 1-Eicosanol & 7.84 & 298 \\
\hline 3 & (-)-Mellein & 8.08 & 178 \\
\hline 4 & Diethyl Phthalate & 8.26 & 222 \\
\hline 5 & 4-((1E)-3-Hydroxy-1-propenyl)-2-methoxyphenol & 10.73 & 180 \\
\hline 6 & Phenol, 3-isopropoxy-5-methyl- & 11.36 & 222 \\
\hline 7 & Phthalic acid, heptyl 4-nitrophenyl ester & 12.23 & 385 \\
\hline 8 & 9,9-Dimethoxybicyclo[3.3.1]nona-2,4-dione & 12.48 & 212 \\
\hline 9 & Didodecyl phthalate & 12.61 & 502 \\
\hline 10 & 9,9-Dimethoxybicyclo[3.3.1]nona-2,4-dione & 13.33 & 212 \\
\hline 11 & Phytol & 14.37 & 296 \\
\hline 12 & 9,12-Octadecadienoic acid (Z,Z)- & 14.61 & 280 \\
\hline 13 & 1,2-9,9-Dimethoxybicyclo[3.3.1]nona-2,4-dione & 14.65 & 212 \\
\hline 14 & 9-Octadecenamide, $(Z)$ - & 14.71 & 281 \\
\hline 15 & 9-Octadecenamide, $(Z)$ - & 15.84 & 281 \\
\hline 16 & Citronellol epoxide (R or S) & 15.98 & 172 \\
\hline 17 & 9,19-Cyclolanostan-3-ol, acetate, (3.beta.)- & 17.29 & 470 \\
\hline 18 & Cholest-4-en-3-one & 18.11 & 384 \\
\hline 19 & 9,9-Dimethoxybicyclo[3.3.1]nona-2,4-dione & 18.75 & 212 \\
\hline 20 & cis-1,2-Cyclododecanediol & 19.69 & 200 \\
\hline
\end{tabular}




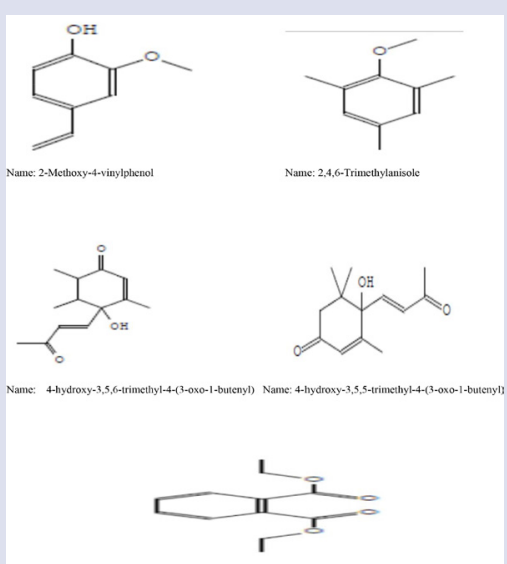

Figure 9: Structures of components identified by GC-MS.

pounds such as 9, 12-octadecadienoic acid Z, Z) - were also present. The presence of various bioactive compounds in the B. Sapida justifies the use of the plant for various ailments by traditional practitioners. However, isolation of individual phytochemical constituents and subjecting it to the biological activity assays will definitely give useful results.

Furthermore, the phenolic hydroxyl group present in compounds 2-methoxy-4-vinylphenol and 4-hydroxy-3, 5, 6-trimethyl-4-(3-oxo1-butenyl) could directly or indirectly be the key feature that contributed to the higher antioxidative and antidiabetic effects depicted by the stem extracts. The low reduction potentials of phenolics, hydroxyls and other related compounds inactivate and terminate the initiation and propagation of chain reactions associated with oxidative damage (Nagababu et al. 2010). In a similar way, phenolics and hydroxyls were reported to interfere with some surface amino acid side chains in both a-amylase and a-glucosidase structures (Ludwig 2002). This causes some conformational changes in the enzyme structure, thereby decreasing their actions and causing a reduction in blood glucose levels and subsequently reduced postprandial hyperglycemia.

\section{CONCLUSION}

Based on the findings of this study, it can be concluded that ethanol stem bark extract of Blighia sapida K.D. Koenig possesses antioxidative as well as effective $\alpha$-glucosidase and $\alpha$-amylase inhibitory effects. Hence, it is recommended that bioassay-guided fractionation of the ethanol extracts could be done in order to fully investigate the in vivo antidiabetic and antioxidative effects of this extract, isolating the active principle and subjecting it to in vivo antidiabetic evaluation.

\section{ACKNOWLEDGMENT}

The Authors wish to acknowledge the Department of Biochemistry, Afe Babalola University for Providing the necessary facilities to carry out this study.

\section{COMPETING INTERESTS}

The authors declare no conflict of interest.

\section{ABBREVIATIONS USED}

Blighia sapida: B. sapida g: gram; GAE: Gallic acid equivalents; GC-MS: gas chromatography-mass spectrometry; DMSO: dimethylsulfoxide
(DMSO), DNS: Dinitrosalicylic acid; DPPH: 1,1-diphenyl-2-picrylhydrazil; pNPG: p-nitrophenyl-a-D-glucopyranoside; NIST: National Institute of Standards and Technology.

\section{REFERENCES}

1. Abolaji OA, Adebayo AH, Odesanmi OS. Nutritional qualities of three medicinal plant parts (Xylopia aethiopica, Blighia sapida and Parinari polyandra) commonly used by pregnant Women in the Western Part of Nigeria. Pak $J$ Nutr.2007;6(6):665-8.

2. Adefegha SA, Oboh G. Inhibition of key enzymes linked to type 2 diabetes and sodium nitroprusside-induced lipid peroxidation in rat pancreas by water extractable phytochemicals from some tropical species. Pharm Biol. 2012; 50(7):857-65.

3. Ademiluyi A, Oboh G. Soybean phenolic-rich extracts inhibit key-enzymes linked to type 2 diabetes ( $\alpha$-amylase and $\alpha$-glucosidase) and hypertension (angiotensin converting enzyme) in vitro. Exp Toxicol Pathol. 2013;65(3):305-9.

4. Aderinola OA, Farinu, GO, Akinlade JA, Olayemi TB, Ojebiyi OO, Ogunniyi PO. Nutritional potential of Blighia sapida Koenig (Ackee) leaves as a dry season feed resources foe West Africa dwarf Goats in the derived savanna zone of Nigeria. Livestock Res Rural Dev. 2007;19(6):1-5.

5. Ali $H$, Houghton PJ, Soumyanath A. $\alpha$-Amylase inhibitory activity of some Malaysian plants used to treat diabetes: with particular reference to Phyllantus amarus. J Ethnopharmacol. 2006;107(3):449-55

6. Al-Zuhair S, Dowaidar A, Kamal H. Inhibitory effect of dates-extract on $\alpha$-Amylase and $\alpha$-glucosidase enzymes relevant to non-insulin dependent diabetes mellitus. J Biochem Tech. 2010;2(2):158-60.

7. Bachhawat AJ, Shihabudeen MS, Thirumurugan K. Screening of fifteen Indian ayurevedic plants for alpha-glucosidase inhibitory activity and enzyme kinetics. Int J Pharm Pharm Sci. 2011;3(4):267-74.

8. Dastmalchi K, Dorman HJD, Korsa M, Hiltunen R. Chemical composition of in vitro antioxidant evaluation of a water soluble mediavan balm (Dracocephalum moldavica L.) extract. Lebensmittel-Wissenschaft Technol. 2007;40:239-48.

9. Esuoso KO, Odetoun SM. Proximate chemical composition and possible industrial utilization of $B$. sapida seed and oils. J Phytotherapy Res. 2005;72(7):311-3.

10. Gyamfi MA, Yonamine M, Aniya Y. Free-radical scavenging action of medicinal herbs from Ghana: Thonningia sanguinea on experimentally-induced liver injuries. Gen Pharmacol. 1999;32(6):661-7.

11. Hassall $\mathrm{CH}$, Reyle L. Hypoglycin A and B, two biologically active polypeptides from Blighia sapida. Biochem J. 1955;60(2):334-9.

12. Hossain SJ, El-Sayed MA, Mohamed AH, Shehed M, Aoshima H. Phenolic content, anti-oxidative, anti- $\alpha$-amylase and anti- $\alpha$-glucosidase activities of Solanum diphyllum L. Bangladesh J Bot. 2009;38(2):139.

13. IDF.2014. Global Diabetes Scorecard-Tracking Progress forAction. Brussels, Belgium, 104

14. Ibrahim M, Koorbanally N, Islam MD. Antioxidative activity and inhibition of key enzymes linked to type- 2 diabetes ( $\alpha$ - glucosidase and $\alpha$ - amylase) by Khaya senegalensis. Acta Pharm. 2014;64(3):311-24.

15. Jimoh TO, Buoro AT, Muriana M. Utilization of Blighia sapida (Akee apple) pod in the removal of lead, cadmium and cobalt ions from aqueous solution. J Environ Chem and Ecotoxicol. 2012;4(10):178-87.

16. Kajaria DR, Tripathi J, Tripathi YB, Tiwari S. In-vitro $\alpha$ amylase and glycosidase inhibitory effect of ethanolic extract of antiasthmatic drug - Shirishadi. J Adv Pharm Technol Res. 2013;4(4): 206-9.

17. Kamiyama $O$, Sanae $F$, Ikeda K, Higashi $Y$, Minami $Y$, Asano $N$, et al. In vitro inhibition of a-glucosidases and glycogen phosphorylase by catechin gallates in green tea. Food Chem. 2010;122(4):1061-6.

18. Kane MP, Abu-Baker A, Busch RS. The utility of oral diabetes medications in type 2 diabetes of the young. Curr Diabetes Rev. 2005;1(1):83-92.

19. Kang W, Song Y, Gu X. $\alpha$-glucosidase inhibitory in vitro and antidiabetic activity in vivo of Osmanthus fragrans. J Med Plants Res. 2012;6:2850-6.

20. Kawamura-Konishi Y, Watanabe N, Saito M, Nakajima N, Sakaki T, Katayama T, et al. Isolation of a new phlorotannin, a potent inhibitor of carbohydrate-hydrolyzing enzymes, from the brown algae Sargassum patens. J Agric Food Chem. 2012;60(22):5565-70.

21. Kazeem MI, Raimi OG, Balogun RM, Ogundajo Al. Comparative Study on the $\alpha$-amylase and $\alpha$-glucosidase Inhibitory potential of Different Extracts of Blighia sapida Koenig. Am J Res Comm. 2013;1(7):178-192.

22. Kazeem MI, Ogungbe SM, Saibu GM, Aboyade OM. In vitro study on the hypoglycaemic potential of Nicotiana tabacum leaf extracts. Bangladesh J Pharmacol. 2014;9(2):140-5.

23. Keay RJ. Trees of Nigeria. Clarendon Press. 1999;19-21.

24. Ludwig DS. The glycemic index: physiological mechanisms relating to obesity, diabetes, and cardiovascular disease. J Am Med Assoc. 2002;287(18):2414-23.

25. Mcdonald S, Prenzier PD, Autokiwich M, Robards K. Phenolics content and antioxidant activity of olive oil extracts. Food Chem. 2001;73:73-84. 
26. Kwon YI, Apostolidis E, Kim YC, Shetty K. Health benefits of traditional corn, beans and pumpkin: in vitro studies for hyperglycemia and hypertension management. J Med Food. 2007;10(2):266-75.

27. Minotti G, Aust SD. An investigation the into the mechanism of citrate-Fe2+dependent lipid peroxidation. Free Rad Biol Med. 1987;3:379-87.

28. Mohd-Esa N, Hern FS, Ismail A, Yee CL. Antioxidant activity in different parts of roselle (Hibiscus sabdariffa) extracts and potential exploitation of their seeds. Food Chem. 2010;122(4):1055-60.

29. Nagababu E, Rifkind JM, Sesikeran B, Lakshmaiah B. Assessment of Antioxidant Activity of Eugenol in vitro and in vivo Methods Mol Biol. 2010;610:165-80.

30. Oboh G, Rocha JBT. Distribution and antioxidant activity of polyphenols in ripe and unripe tree pepper (Capsicum pubescens). J Food Biochem. 2007;31(4):456-73.

31. Oboh G, Raddatz H, Henle T. Antioxidant properties of polar and non-polar extracts of some tropical green leafy vegetables. J Sci Food Agric. 2008; 88(14):2486-92.

32. Ojo OA, Oloyede OI, Olarewaju OI, Ojo AB. In vitro Antioxidant Activity and Estimation of Total Phenolic Content in Ethyl Acetate Extract of Ocimum gratissimum. Pharmacology Online. 2013a;3:37-44.

33. Ojo OA, Oloyede OI, Olarewaju OI, Ojo AB, Ajiboye BO Onikanni SA. In-vitro antioxidant and free radical scavenging activities of Ocimum gratissimum. Wr J Pharm Res. 2013b;2(6):1899-12.

34. Ojo OA, Oloyede OI, Tugbobo OS, Olarewaju OI, Ojo AB. Antioxidant and inhibitory effect of scent leaf (Ocimum gratissimum) on $\mathrm{Fe}^{2+}$ and sodium nitroprusside induced lipid peroxidation in rat brain in vitro. Adv Biol Res. 2014;8(1):8-17.

35. Ojo, OA., Ojo, AB., Ajiboye B.O., Oyinloye, B.E., Imiere, O, Adeyonu, O. (2017). Ameliorative potentials of Blighia sapida K.D. Koenig bark against pancreaticcell dysfunction in alloxan-induced diabetic rats. Journal of Complementary and Integrative Medicine, 14(3) Article number 20160145 doi: https://doi. org/10.1515/jcim-2016-0145.
36. Oloyede OB, Ajiboye TO, Abdussalam AF, Adeleye AO. Blighia sapida leaves halt elevated blood glucose, dyslipidemia and oxidative stress in alloxan-induced diabetic rats. J Ethnopharmacol. 2014;157:309-19.

37. Owonubi OM. Some Pharmacognostical Studies on Bligha sapida. Med Plant Res. 1996;12:187-95.

38. Pulido R, Bravo L, Saura-Calixto F. Antioxidant activity of dietary polyphenols as determined by a modified ferric reducing/antioxidant power assay. Journal of Agricultural and Food Chem. 2000;48(8):396-402.

39. Puntel RL, Nogueira CW, Rocha JBT. Krebs cycle intermediates modulate Thiobarbituric Acid Reactive Species (TBARS) production in rat brain in vitro. Neurochem Res. 2005;30(2):225-35

40. Saidu AN, Mann A, Onuegbu CD. Phytochemical Screening and of Aqueous Blighia sapida Root Bark Extract on Normoglycemic Albino Rats. Brit J Pharm Res. 2012;2(2):89-97.

41. Shai LJ, Masoko P, Mokgotho MP, Magano SR, Mogale AM, Boaduo N, et al. Yeast alpha glucosidase inhibitory and antioxidant activities of six medicinal plants collected in Phalaborwa, South Africa. South Afr J Bot. 2010;76(3):465-70.

42. Shim YJ, Doo HK, Ahn SY. Inhibitory effect of aqueous extract from the gall of Rhus chinensis on $\alpha$-glucosidase activity and postprandial blood glucose. J Ethnopharmacol. 2003;85(2):283-7.

43. Singh J, Baghotia A, Goel SP. Eugenia caryophyllata Thunberg (Family Myrtaceae): A Review. Int J Res Pharm Biomed Sci. 2012;3(4):1469-79.

44. Tuba AK, Gulcin I. Antioxidant and radical scavenging properties of curcumin Chemico Biol Inter. 2008;174(1):27-37.

45. Veronica MD, Agbenorhevi JK, Combey S, Afi-Koryoe S. Ackee (Bilghia sapida) fruit arils: Nutritional, phytochemicals and antioxidant properties. Int J Nut Food Sci. 2014;3(6):534-7.

\section{GRAPHICAL ABSTRACT}

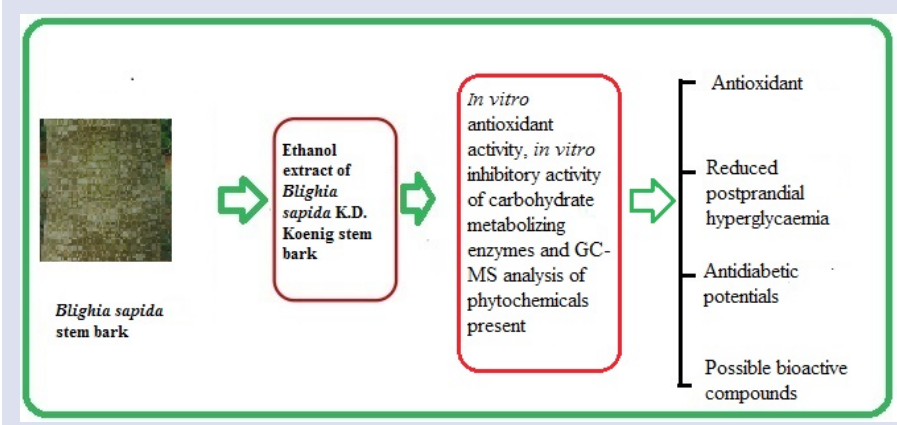

\section{SUMMARY}

- Blighia sapida stem extract possess strong anti-diabetic activity via

- Inhibition of carbohydrate hydrolyzing enzymes such as $\alpha$-amylase and $\alpha$-glucosidase activity.

- Possess good antioxidant activity which supports its uses in the management of hyperglycaemia and its associated complications in type-2 diabetes mellitus

- This inhibitory activity may be attributed to the action of their inherent polyphenols.

- GC-MS analysis reveals bioactive compounds such as phenolics

\section{ABOUT AUTHORS}

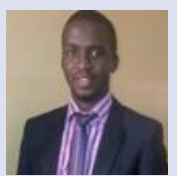

Oluwafemi Adeleke Ojo: Is an academic researcher at Afe Babalola University, Ado-Ekiti, Nigeria. He has published more than 30 peer review research articles, and 10 conference proceedings. The author's work has been published in Phytomedicine, Medical, Pharmacology and Pharmacognosy journals. His research work is focused on the Anti-Diabetic Potentials and Associated Molecular Mechanism of Bioactive Compounds in African Medicinal Plants. He has projects in collaboration with International institutions.

Cite this article: Ojo OA, Ajiboye BO, Imiere OD, Adeyonu O, Olayide I, Fadaka A. Antioxidative Properties of Blighia sapida K.D. Koenig Stem Bark Extract and Inhibitory Effects on Carbohydrate Hydrolyzing Enzymes Associated with Non-Insulin Dependent Diabetes Mellitus. Pharmacog J. 2018;10(2):376-83. 